\title{
BASICS OF OPTIMIZATION STRATEGY FOR INTEGRATING SPACE INDUSTRY TECHNOLOGY PACKAGE INTO GLOBAL VALUE CHAINS
}

\author{
Vitaliy OMELYANENKO
}

Sumy State University, Ukraine

Corresponding author e-mail:v.omelyanenko@macro.sumdu.edu.ua

\begin{abstract}
The article deals with basic characteristics and fundamentals of innovation management of global value chains and considerations on the example of space industry based on the factor of interaction in the creation of new products in global value chains. General context of global value chains as a factor of strategy development and characteristics and factors of global value chains in space industry is considered. Mechanism of the development of space engineering as global industry at the national level is proposed. The author proposes to consider four groups of level of characteristics of the competitiveness of technological component for integration into the global value chain of space industry projects.
\end{abstract}

Keywords: Strategy, space industry, technological package, international cooperation, global value chains, innovations.

\section{INTRODUCTION}

The increasing intensity of integration processes in world economy, deepening of the division between international labour and cooperation, increasing of complexity of modern high-tech production technological base lead to changes in scientific and technical equilibrium, but only some of the developing countries, will reach the level of technology to compete with the leaders. China is holding a strong position and can try to catch up with the rapid achievements of the EU Member States and reach the level of the USA. Other BRIC countries do not have enough resources to reduce the backlog. India and Brazil show themselves in certain areas, but the overall level of these countries is still lower in comparison with technology leaders such as the EU, the USA and Japan.

At the same time high-tech development requires its realization through the "cooperation-competition" model. Cooperation deals with networks, where the first type of linkages is priority, characterized by high degree of openness and symmetric dependence partners. But there can also appear a situation of asymmetrical cooperation when some partners do not receive benefits.

The mentioned factors impose certain requirements for organization and development of international innovation cooperation in high-tech industries as the advantage of a country's technology gives it a priority position in world markets and at the same time increases its own innovation potential through synergetic effects. 
Decision making in these conditions requires deep understanding not only of nature and pace of evolution of highly efficient technologies, but also a wider view of industries to conduct quantitative and qualitative analysis of innovations. In order to inform about the future of technological prospective and provide practical recommendations for new opportunities, it is necessary to develop methodological approach for analysis.

One of the suitable approaches that is posing new challenges for the analysis of the role of countries in global economy and their competitiveness is considering global value chains (GVCs). The importance of this study is in understanding that the value chain analysis also allows to identify economic actors who control and coordinate economic activity in innovation and production networks.

The characteristic features of high-tech industries defining their role in economy and the potential formation of global value chains are:

- growth rate, that is 3-4 times faster than the growth of other industries;

- large share of value added in final product;

- significant volumes of exports and high innovation potential, which can provide not only the main sector, but also related industries.

As a result of operation of such industries in national and world economy some kind of innovation "chain reaction" is created. These essential qualities of high-tech industries make them the priority field of global innovation system, as well as the main object of venture capital investments.

According to Porter (1985) the value chain participants can be evaluated using the following criteria: pricing, capital intensity, talent leverage, structural fit, workflow and specialization, customer acquisition. In this study the factor of specialization that can be evaluated through the global value chains will be considered.

The aim of this study is to analyse the features of integration of countries, different public and private actors involved in space industry development and in global value chains and national industry technology package optimization based on the analysis of global value chains to ensure national technological independence.

\section{METHODS AND PROCEDURES}

The main objective of the study is to consider the task of development and management of technological package as a functionally related group of technologies that have system properties allowing to obtain some product. Also, in the context of the article's purpose it is suggested to use the analysis of innovation in internationalization and globalization based on technological convergence (mutual influence and interpenetration and technologies) and innovation system approach (a set of conditions for the successful creation and development of innovation and technology transfer).

In the context of innovation internationalization and globalization technological package can be considered as a global value chain, in which technologies, created in different national innovation systems, have some role and 
importance. So the technological package concept can be regarded as rational basis for analysis in this research.

As a basic methodology of this research it is proposed to consider cross-sectoral linkages as tools of technology analysis and policy development as a system approach, which ensures an integrated development of high-tech products and associated processes from the product concept development to the disposal stage, which is the base for global value chains.

The indicated approach is very important for establishing integrated national innovation systems that as it was noted in previous studies on the example of crosssectoral inter-cluster cooperation (Omelyanenko, 2014a) is an important part of innovation and technological security policy.

\section{GENERAL CONTEXT OF GLOBAL VALUE CHAINS}

Experts of Duke University Centre on Globalization, Governance \& Competitiveness (Duke CGGC) in Global Value Chains Initiative define that value chain "describes the full range of activities that firms and workers do to bring a product/good or service from its conception to its end use and beyond. This includes activities such as design, production, marketing, distribution and support to the final consumer" (Stacey, 2016).

The concept of global value chains has been introduced in scientific analysis in early 2000s and integrates one of the features of modern world economy: growing process of fragmentation of production among growing number of countries and production networks, development of global buyers and global suppliers (Krapyvny, Omelyanenko, \& Vernydub, 2015). Global value chains help to understand the nature of trade and production trends, interdependence of economies, extent to which export competitiveness is associated with cost-effective choice, as well as the availability of end-manufacturers and consumers abroad.

Ensign (2001) suggests that external strategic linkages of economic agent result in two types of interrelationships: inter-firm interrelationships and network interrelationships. The critical element in responding to competitive forces is the firm's ability to identify and manage network linkages.

The index of participation in global value chains is calculated as a share of foreign intermediate goods plus domestically produced intermediate goods used for export to third country as a percentage of gross exports. The effect of chain factors in some sectors of economy is shown in Fig. 1.

European Commission Project World Input-Output Database (WIOD) showed, that China's share of exports of high-tech data is inflated because of the costs of high-tech products made in China, actually only 3-4\% are Chinese, while the remaining part of costs are carried out in other countries.

In G20-Summit in Los Cabos in June 2012, G20-leaders have resumed that “... importance of regional and global value chains for global trade, recognition of their role in economic growth stimulating, employment and development as well as the necessity for broader participation of developing countries in in such value chains". But at the same time the growth of global value chains has reinforced the interdependency: $30 \%$ to $60 \%$ of G20 countries exports consist of imported 
resources or are used as resources in other countries (Consequences of global value chains..., 2016).

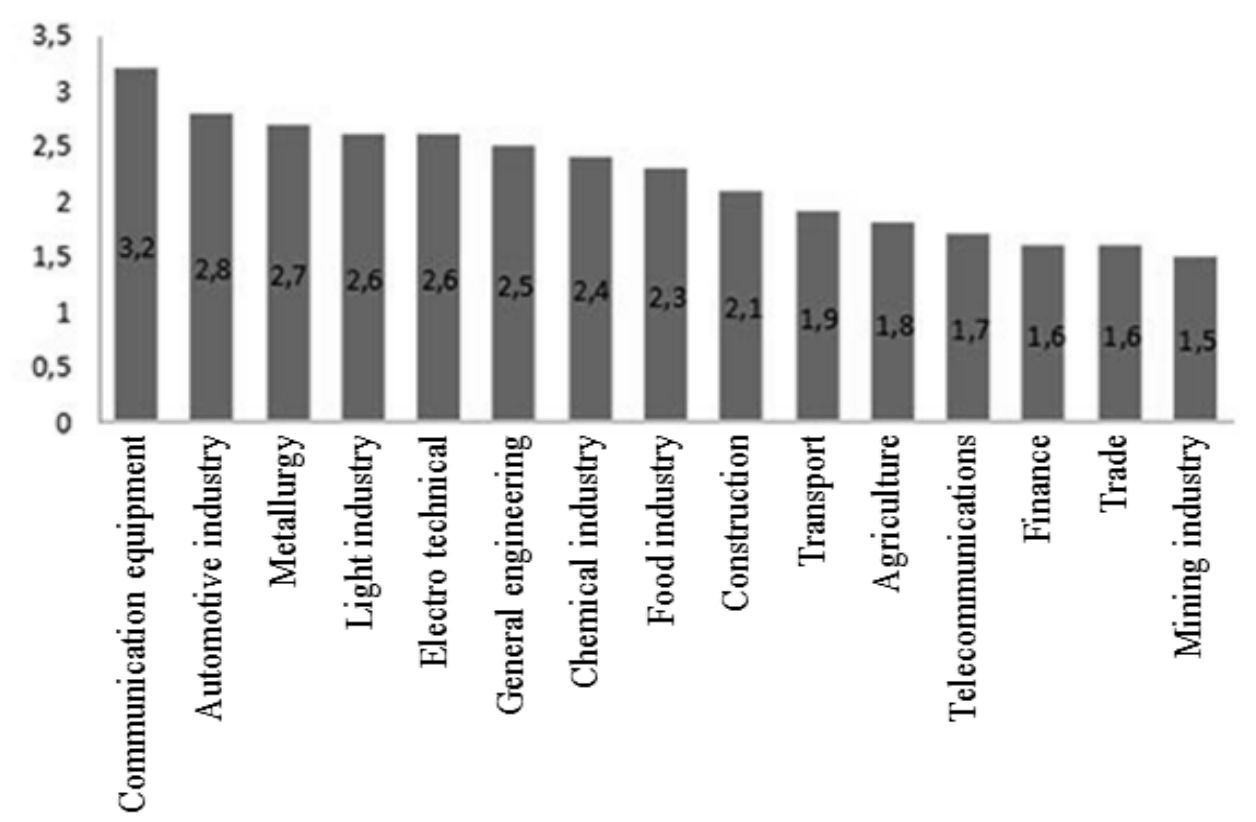

Fig. 1. The length of Global Value Chains by Industries (Kondratyev, 2014)

It is with full confidence that we can underline, that a simple chain analysis based on the principle of the manufacturing country is not enough. Timmer et al. (2013) emphasise that industrial and trade policy therefore should not be sectorspecific but rather focus on the type of activities carried out along international production chains.

For example, if a specific export product contains a number of imported semifinished products, the share of domestic value added is low, and therefore the gross export trade flow or the fact country of origin will tell not enough about the real competitiveness of the country or industry.

Especially clearly the global value chains can be observed in high tech sectors. For example, on Apple iPhone we can read: "Designed by Apple in California. Assembled in China". Thus the strategy of participation in global supply chains in modern conditions is the basis of global high-tech production.

In the context of the analysis it should be noted that any high technology should be regarded as a complex system that has a life cycle, i.e. period from the beginning to expediency of its further use. Accordingly, the technology cannot be considered separately from at least one of its basic or even supporting elements. Scientific and technological progress is dynamic in its nature and there always appears something new - materials, products, structures, machinery, improved automation, etc. Therefore, new technology does not appear alone and is the product of complex use of scientific achievements in a certain period of time. Consequently, the technology and the level of its competitiveness are also changing. 
OECD Report (OECD, 2015), which is a part of larger work programs of OECD and World Bank Group, supports countries' policies on global value chain integration with analysis and capacity building for leveraging global value chains for the growth and development. The report focuses on making global value chains more "inclusive". However, "inclusive" does not always means effective because specialization in global value chain may strengthen the negative trends and effects in economy (resource exploitation, cheap labour, etc.).

On this basis, we propose to consider the competitiveness of technological package in space industry. In our previous studies (Omelyanenko, 2014b) we have shown that in the context of limited resources and scientific and technical capabilities it is important to optimize the technological package of high technology industries (i.e. select the most efficient specialization), especially of space industry, which integrates the latest advances in science and technology and at the same time is their catalyst. We can see also essential synergies between institutional programs and commercial competitiveness.

\section{GLOBAL VALUE CHAINS IN SPACE INDUSTRY}

Space industry is one of the sectors that allows the developing countries, that have innovation capacity develop some innovation at international level and at the same time promote economic development (Omelyanenko, 2015; Arbatov \& Dvorkin, 2009). In our previous studies we have considered the main features of space economy as a full range of activities and the application of resources, which create value and benefits for the human beings based on exploring, researching, understanding, managing, and utilizing space (Prokopenko, Zhekov, \& Omelyanenko, 2014).

Space economy during a relatively short period has become a relevant domain for high-tech innovation as well as for strategic purposes and commercial opportunities. Different kinds of involved agents, activities, inputs and processes contribute to shape naturally the space sector's global value chain.

The main value chain features of space industry are:

- Partnerships: growing number of domestic and international partnerships and projects;

- Science, technology \& innovation: increased number of international patent applications in last 3 years;

- Capital \& finance: availability of multiple space-relevant funding sources;

- Human capital: growing enrolment in science, technology, engineering and mathematics (STEM) at the universities.

Due to the growing availability of space (mainly satellite) technologies the number of countries developing space activities is increasing - at present according to different calculations there are about 80 countries (e.g. government expenditures for space programmes from 1990 and 2013 is shown in Fig. 2.

On the other hand, computerization of domestic economic processes enforce many states to seek independent possession of space technologies (some countries 
for some reasons use space services of third countries on commercial basis), to develop their own technology or use other countries' services.
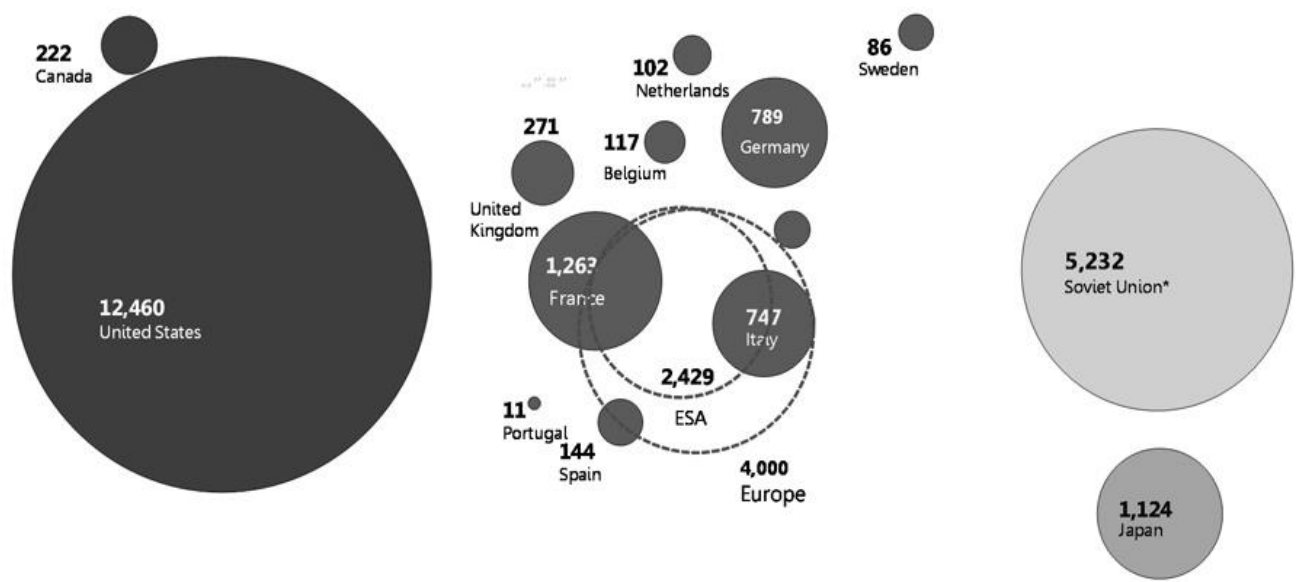

a)

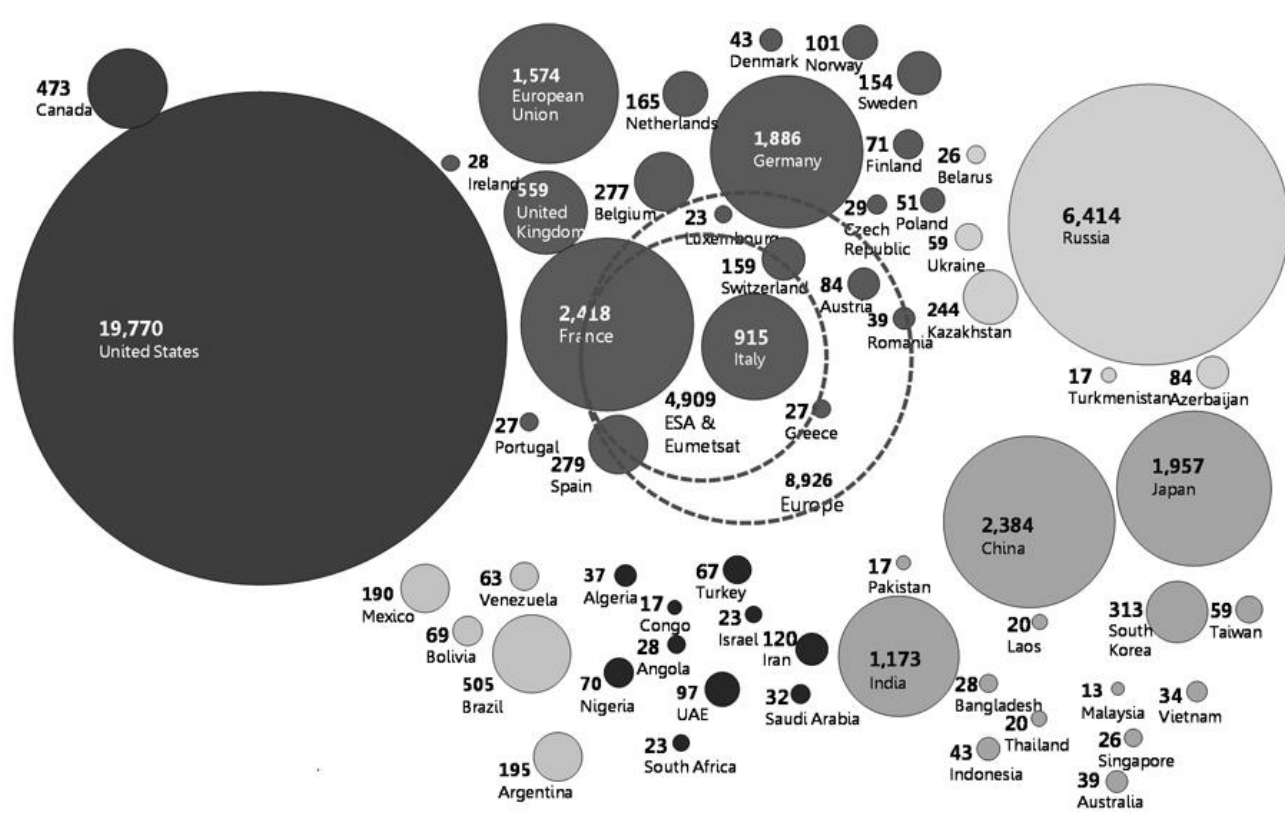

b)

Fig. 2. Government expenditures for space programmes, 1990 and 2013 (only the countries spending over $\$ 10$ million): a) 15 countries in 1990; b) 58 countries in 2013 (Euroconsult, 2015).

Experts of FLB Partners, Strategy Consulting and Business Intelligence (FLB Partners, 2016) notice two main tendencies in the global space sector related to our study: (i) development of supply chains for space systems and increasingly evolving operation at international level, even if space remains heavily influenced and shaped by strategic and security considerations; (ii) stronger competition for 
incumbent players on commercial open markets of spacecraft, launcher systems and equipment/components, as more actors wish to enter into global value chains.

According to "The Space Economy at a Glance: 2007" (Jolly \& Razi, 2007) space industry is characterized by long value-added chain, which starts with $R \& D$ actors and space hardware manufacturers and ends with providers of different space-enabled products and services to final users.

In Handbook on Measuring the Space Economy (OECD, 2012) space economy is considered as "the full range of activities and the use of resources that create and provide value and benefits to human beings in the course of exploring, understanding, managing and utilizing space. Hence, it includes all public and private actors involved in developing, providing and using space-related products and services, ranging from research and development, the manufacture and use of space infrastructure (ground stations, launch vehicles and satellites) to spaceenabled applications (navigation equipment, satellite phones, meteorological services, etc.) and the scientific knowledge generated by such activities".

This means that the Space Economy goes well beyond the space sector itself, since it also comprises the increasingly pervasive and continually changing impacts (both quantitative and qualitative) of space-derived products, services and knowledge on economy and society.

Figure 3 illustrates the example of value chain in space industry specifics. Another example was given by experts of Euroconsult (2015) who analysed other three value chains, developed for the provision of commercial services from the satellite systems application: communications (Satcom), Earth observation (EO), and navigation (Satnav).

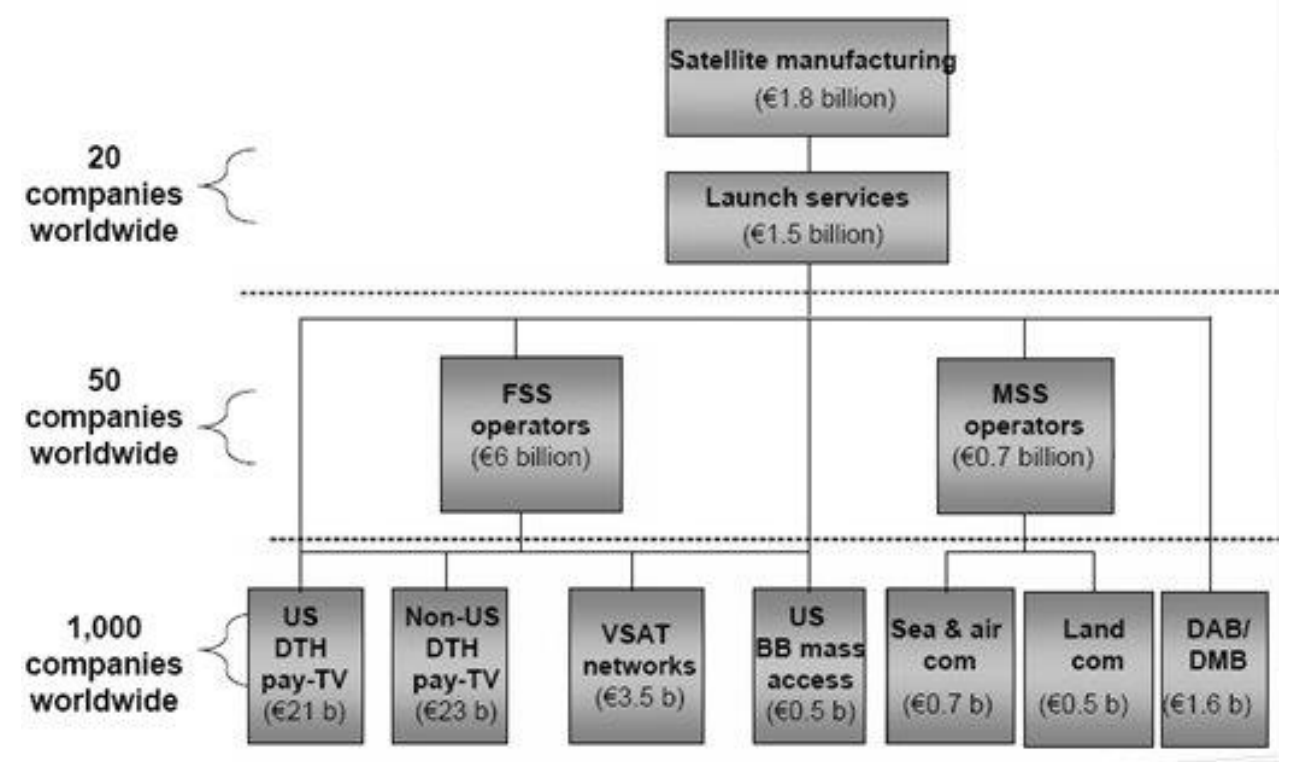

Fig. 3. Satellite technology value chain (ESOA, 2015).

Oxford Economics have suggested that high percentage of turnover in space sector (more than $50 \%$ ) is accounted for added value (The Case for Space..., 2009). 
Space industry refers to the production of high cost of added value and highest performance requirements to different products and services that provides the development of big number of high-tech sectors. Consequently, the industry is characterized by the formation of largest chains of added value, which is largely dependent on R\&D.

The global market of space technologies can be divided into three sectors:

1. Manufacture, including parts of rockets and necessary equipment;

2. Services, including satellite navigation (GPS), satellite communications (satellite TV and satellite, Internet) services and earth observation (for example, control of land use, weather forecasts, etc.);

3. Industries, related to the above mentioned services (specific means of communication, disaster management, etc.).

Given the practical aspect of relationship between these areas and contrast with the problem of formation of effective result object in space industry (spacecraft), we offer to consider separately the components of production chains and project chains (including many different components of production chains).

\section{STRATEGY OF SPACE INDUSTRY BASED ON GLOBAL VALUE CHAINS}

Analysis of the experience in designing modern complicated technical systems shows that the implementation of measures for spacecraft creation in early design stages is technically and organizationally complicated and also a multi-step process (Melder, Stupina, \& Verhorubov, 2013). The main difficulties that are connected with the problem of choosing optimal parameters of technical system, especially in early stages of its design, have less to do with the application of mathematical optimization techniques, than with the problem formulation and selection criteria.

At the same time the use of spacecraft imposes a list of requirements for the production technology of its components, the principal ones being: precision characteristics according to the technical requirements; small weight and overall dimensions; low power consumption; increased active lifetime; development and manufacturing deadlines; acceptable cost, etc. We believe, that, given the interdependence of technologies, the project chain should be considered as a form of global innovation network in which fundamental technologies are developed.

Thus based on specialization differences I propose to consider the significance level of components (Fig. 4). Artyukhov, Omelyanenko \& Artyukhova (2016) suggest using the technological package approach considered in their previous studies. The task of forming and management of technological package as a functionally related group of technologies that is characterized by system properties is an important integrated innovation management objective. So we face the task of improving efficient core closed elements along the value chain. According to Prahalad \& Hamel (1990) the core products are the components, which actually contribute the value to final products.

Analysis of different space projects shows their international character despite significant efforts of "nationalization" of their core closed elements (through the creation of global complete cycle corporations), i.e. the desire to form closed 
national technological package, that in conditions of increasing complexity and scale of industry problems (space colonization, increased flight distance, accuracy of research and so on) is impossible.

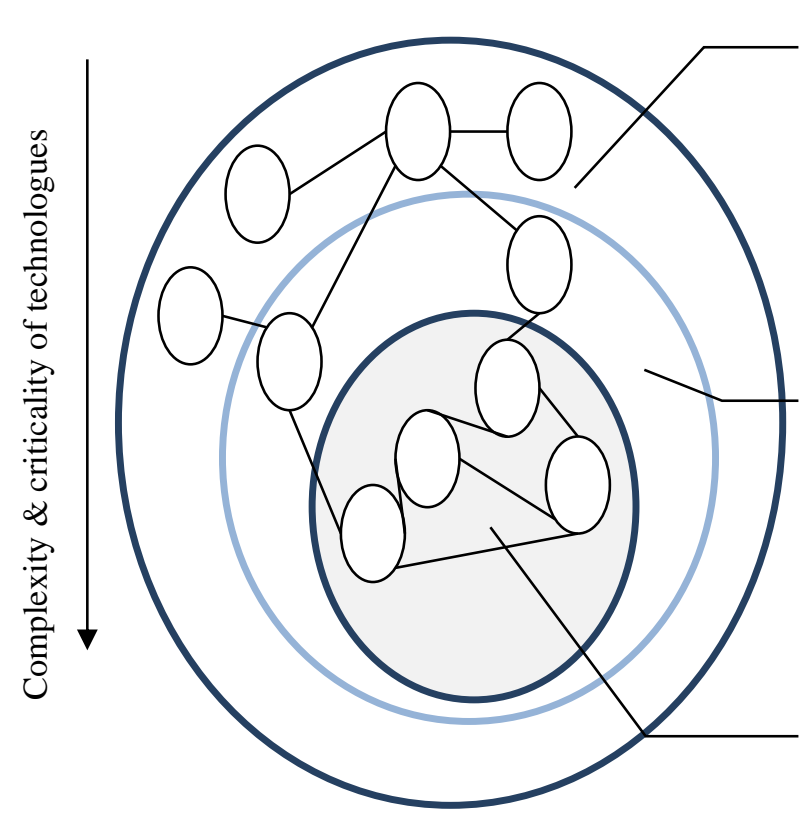

Periphery technologies

Are known and are the basis of production processes and are not tools in competition

Complementary technologies

Are known and are tools in competition only in technological package

Core (Basic technology)

Are owned by a limited number of companies (or just one) and ensure the possibility of key competitive advantages in the market for some time

Fig. 4. Value chain scheme based on technological package concept.

Therefore for analysis the author proposes to use the indicator of internationalization level of technological package in general as well as internationalization level of its individual components, selected according to the significance criteria. It is suggested that the offered level of internationalization is understood as ratio of industrial components of participants who are not the final project operators (customers). This analysis should be conducted together with the calculation of the ratio of national contribution to component production (for example, patent, owned by a country's resident, or is joint with foreign partner).

Based on the list of interplanetary space crafts, launched in 1958-2011, as well as the states and space agencies, involved in launches and sectoral researches (List of interplanetary space crafts, 2016), in which we have included successful, ongoing and planned mission, it can be argued, that the number of countries, which are the parties of this process, is significantly increasing, as well as the number of planned international missions (excluding the purchase of components for production) is growing. Also the share of the EU participating as a collective agent in these processes is also growing. 
We offer to consider four groups of characteristics of the level of competitiveness of technological component for integration into the global value chain of space industry project (projects):

1. Basic characteristics that include the quality characteristics of established production technology, novelty criteria (new in country, new abroad, principally new), number of patents on intellectual property objects by types, beginning period of the implementation;

2. Integration characteristics, i.e. characteristics of technology that determine its usefulness as part of some project and allow to integrate it with other technologies and solutions for the realization of goal of technological package. It is proposed to include in these characteristics the following:

- Level of matching with project objectives (maximization of the realization of objective function, i.e. the core);

- Period of integration with other project components. For example, basic requirements for space-craft instruments is the miniaturization of its component size that can significantly affect the original specifications of "on-ground" developed device. It has also an important role in automation, distributed computing and remote control informatization, etc.;

- Reduction or improvement of basically and (or) appearance of new characteristics after the integration with other project components. On the basis of this project it is possible to implement measures for increasing the competitiveness of other partners;

3. Characteristics of inter-sectoral transfer potential (potential of "civil" commercialization of technology) that are based on fundamental and applied results obtained in the development of technology, as well as its potential for commercial use in other sectors;

4. Characteristics of strategic partnership, i.e. ability to identify prospective technology development partners and establish strategic partnership with them.

International cooperation in establishment and operation of rocket and space technologies, evolving in last decade, determines the need for harmonization of technical requirements for products created by different countries. Moreover, these products (assemblies, systems, devices and others) can be produced and used in other countries. The most striking examples of these processes are: International Space Station (ISS); program "Sea Launch"; launch facilities in Korea and France (Guiana Space Centre); space technologies machinery; launch space of apparatus of Japan, Germany and other countries from launch spaceports in Baikonur and Plesetsk.

We must also consider the political context of industry development. At the same time parts of the remaining space industry after the collapse of the Soviet space industry have the unity of technological standards. This factor leads to objective necessity for countries to cooperate in space sector for some time.

A clear example is the decision, which was made many years ago, about the application of foreign electronic component base (ECB) in rocket and space technologies in many countries, including CIS countries, which is strategically 
wrong from the point of view of national and technological security. Therefore, the competitiveness of package which was built on the principles of components' production chain integration is quite problematic, as in this case there is a certain technological dependence in the component base field, causing risk to the whole technological package in different crisis situations, especially situations of political nature.

For example, the solution of scientific and technical issues may be prevented by lack of funding or political factors that lead to the fact that the agents are forced to think about the creation of industries, which are independent from each other, i.e. breaking of existing global project chains, which will reduce the path of technological development. Because of this chain gap innovation chain lag is created, i.e. the period of formation of new innovation chains.

Because of this Russian Federation in its sector strategy for a couple of years is going to refuse from foreign electronics in domestic space-crafts. On the other hand, when technologies are critical, there is no such gap situation. For example, European company Arianespace continues to use the rocket "Soyuz" in middle class launch vehicles, and the US continues to use Russian engines. In addition currently "Soyuz" is the only carrier of astronauts to the International Space Station.

These examples confirm the hypothesis about the need for a strategy based on global value chain analysis.

\section{CONCLUSION}

Innovation strategy based on value chains should maintain and increase the share of global market and remain on the cutting edge of technological development with capacity to produce high-tech and be actively involved in cross-sector transfer. The study shows that in order to develop worldwide competitiveness of domestic space industry the sector should be encouraged to become more cost-efficient along its value chain. That is why the rise of global value chains is posing a lot of new challenges for the competitiveness and international trade analyses of the country.

In this context the case of losing of the existing participation in global value chains and considering complementary nature of technological package forms two alternative development models of the sector:

1. Mobilization of the existing potential of innovation system based on technological auditing and concentration of technological and additional resources to address specific technology development tasks, taking into account the criterion of minimizing the time and costs and maximizing the proximity to the core of leading technological package;

2. Conservation of existing specialization, taking into account, that due to loss of target markets the industry can rely only on episodic participation in some projects (predominantly in the initial phase of spacecraft value chain), which are not convenient for key market participants - Russian Federation, USA, China or EU, or establishing partnerships with new space countries. This path can be efficient through strategic partnerships, when existing specialization is significantly improved and the country becomes a highly specialized leader. 
Obviously, the first direction is more effective, but it requires significant efforts in relation to the nature of the system, particularly the necessity of creating the database of domestic and foreign advanced technologies. It also will be useful to use marketing of the scientific and technological image for technology and national innovation system capabilities.

One of the key factors is involvement of private companies in the implementation of national projects that will improve economic efficiency of space projects and their competitiveness. This in turn will make the space industry attractive for foreign companies in terms of cooperation and exchange of new technologies.

So the task of integration strategy into global value chains in space sector is complex and multi objective. The decision should be based on foresight and assessment of the potential of innovation system in the framework of methodology of structural synthesis of integrated information models. As a result, methods of system analysis and spatial-temporal optimization of material, financial and information flows at all stages of the life cycle of high-tech products should be applied.

\section{ACKNOWLEDGMENT}

This work has been supported by the Ministry of Education and Science of Ukraine within the research projects "Methodology of providing the competitiveness of the socio-economic systems in global transformations conditions" (No. 0115U004846) and "Methodology of innovation development mechanism formation of national economy on the basis of alternative energy" (No. 53.15.0101.15/17.ZF).

\section{REFERENCES}

Arbatov, A. \& Dvorkin, V. (2009). Space: Weapons, Diplomacy, Security. Moscow: Carnegie Moscow Center.

Artyukhov, A. Ye., Omelyanenko, V. A., \& Artyukhova, N. O. (2016). Strategic framework and methodical bases of technological package development management. Marketing and Management of Innovations, 3, 170-179.

Consequences of global value chains for trade, investment, development and employment (2013). The G20 summit in St. Petersburg. Retrieved from http://economy.gov.ru/minec/activity/sections/ foreignEconomicActivity/economic_organization/russiaj20j8/doc20131205_7

Ensign, P. C. (2001). Value Chain Analysis and Competitive Advantage: Assessing Strategic Linkages and Interrelationships. Journal of General Management, 27(1), 18-42.

ESOA. (2015). The Space Value Chain. - Credits.

Euroconsult. (2015). Comprehensive Socio-Economic Impact Assessment of the Canadian Space Sector. Final Report. Retrieved from http://www.asc-csa.gc.ca/eng/publications/2015assessment-canadian-space-sector.asp

FLB Partners. (2016). Aerospace.

Jolly, C. \& Razi, G. (2007). The space economy at a glance: 2007. OECD Publishing.

Kondratyev, V. B. (2014). Global value chain in today's economy. Network edition of Research Center analysts and Historical Perspective Foundation "Perspectives". Retrieved from http://www.perspektivy.info/oykumena/ekdom/globalnyje_cepochki_dobavlennoj_stoimosti_v _sovremennoj_ekonomike_2014-03-17.htm 
Krapyvny, I. V., Omelyanenko, V. A., Vernydub, N. O. (2015). International innovation networks as new stage of innovation development, Economic Processes Management: International Scientific E-Journal, 1. Retrieved from http://epm.fem.sumdu.edu.ua/download/2015_1/2015_1_17.pdf

List of interplanetary space crafts (2016). Retrieved from http://dic.academic.ru/dic.nsf/ruwiki/1870650

Melder, M. I., Stupina, A. A., \& Verhorubov, A. I. (2013). Methods of accelerated flight qualification of new space technologies. Modern problems of science and education, 5.

OECD. (2012). Handbook on Measuring the Space Economy.

OECD. (2015). Inclusive Global Value Chains Policy options in trade and complementary areas for GVC Integration by small and medium enterprises and low-income developing countries OECD and World Bank Group Report prepared for submission to G20 Trade Ministers Meeting (Istanbul, Turkey, 6 October 2015). Retrieved from http://www.oecd.org/trade/OECD-WBGg20-gvc-report-2015.pdf

Omelyanenko, V. A. (2014a). Analysis of Potential of International Inter-Cluster Cooperation in High-Tech Industries. International Journal of Econometrics and Financial Management, 2(4), 141-147.

Omelyanenko, V. A. (2014b). To the question of management of technological packages at the national level. European Journal of Social Sciences, 7(46), 471-478.

Omelyanenko, V. A. (2015). Space technologies transfer as an economic growth driver. Economic Processes Management, 2.

Retrieved from http://epm.fem.sumdu.edu.ua/download/2015_2/2015_2_20.pdf

Porter, M. E. (1985). Competitive Advantage. New York. The Free Press.

Prahalad, C. K. \& Hamel, G. (1990). The core competence of the corporation, Harvard Business Review, 68.

Prokopenko, O. V., Zhekov, Zh., \& Omelyanenko, V. A. (2014). International dimension of technological aspect of space economy. Economic Processes Management: International Scientific E-Journal, 2.

Retrieved from http://epm.fem.sumdu.edu.ua/download/2014_2/2014_2_2.pdf

Stacey, F. (2016). Concept \& Tools. Duke University, Center on Globalization, Governance \& Competitiveness. Durham, NC, USA. Retrieved from https://globalvaluechains.org/concepttools

The Case for Space: The Impact of Space Derived Services and Data Final Report (2009). Commissioned by South East England Development Agency (SEEDA).

Timmer, M., Los, B., Stehrer, R., \& Gaaitzen, De V. (2013). Rethinking competitiveness: The global value chain revolution. CEPR's Policy Portal.

\section{AUTHORS' SHORT BIOGRAPHY}

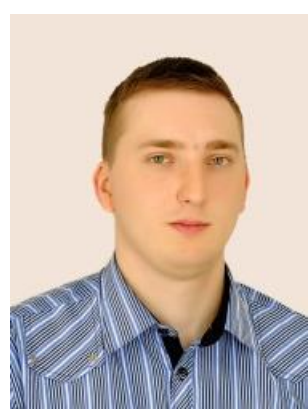

Vitaliy Omelyanenko obtained the Doctoral degree in Economics (World Economy and International Economic Relations) in 2016. He is currently an Assistant Professor with Economic Theory Department at Sumy State University, Faculty of Economics and Management. Since 2015, he has been a Junior Researcher with Sumy State University. Since 2015, he is a Technical Editor of International Scientific E-Journal "Economic Processes Management". He is a member of Ukrainian Political Economics Association.

E-mail: v.omelyanenko@macro.sumdu.edu.ua

ORCID iD: 0000-0003-0713-1444 